\title{
MONITORING COMMON BEAN DEVELOPMENT WITH DIFFERENT WATER AND NITROGEN LEVELS BY SPECTRAL PROPERTIES
}

\author{
Priscylla Ferraz Câmara Monteiro ${ }^{1}$, Rubens Angulo Filho ${ }^{2}$, Rodrigo Otávio Câmara Monteiro ${ }^{3}$, \\ Marcos Adami ${ }^{4}$, Maurício Alves Moreira ${ }^{4}$ \\ ${ }^{1}$ Fundação Estadual de Pesquisa Agropecuária, BR 285, Km 126, CEP 95200-970, Vacaria, RS. E-mail: priscylla- \\ monteiro@fepagro.rs.gov.br \\ ${ }^{2}$ Universidade de São Paulo, Escola Superior de Agricultura Luiz de Queiroz, Av. Pádua Dias, 11, CEP 13418-900, Piracicaba, \\ SP. E-mail: ruangulo@usp.br \\ ${ }^{3}$ Instituto Federal de Educação, Ciência e Tecnologia, Av. Osvaldo Aranha, 540, CEP 95700-000, Bento Gonçalves, RS. E-mail: \\ rodrigo.monteiro@bento.ifrs.edu.br \\ ${ }^{4}$ Instituto Nacional de Pesquisas Espaciais, Av. dos Astronautas 1758, CEP 12227-010, São José dos Campos, SP. E-mail: \\ adami@dsr.inpe.br; mauricio@dsr.inpe.br
}

\section{ABSTRACT}

The aims of this study were to determine the impact of different nitrogen rates and water levels on biophysical (Leaf area index - LAI) and spectral parameters obtained with continuum removal (band depth and area) of bean crop and to determine the growth stage that spectral parameters best correlated with LAI. Absorption band, positioned at $665 \mathrm{~nm}$, was analyzed in depth and width. Field canopy reflectance measurements were acquired at six bean growth stages over 48 plots with four water levels $(179.5 ; 256.5 ; 357.5$ and $406.2 \mathrm{~mm})$, three nitrogen rates $(0$; 80 and $160 \mathrm{~kg} \mathrm{ha}-1)$ and four replicates. The $\mathrm{N}$ had no effect on either absorption band area $\left(\mathrm{A}_{\mathrm{B}}\right)$ or the absorption band depth $\left(\mathrm{P}_{\mathrm{B}}\right)$ of the absorption band centered at $665 \mathrm{~nm}$ (chlorophyll) for the all growth stages. On the other hand, the irrigation level significantly affected these spectral parameters in most growth stages. The best correlations between LAI and absorption band parameters were observed at R6 stage.

Keywords: Phaseolus vulgaris, remote sensing, spectroradiometry, hyperspectral, continuum removal

\section{MONITORAMENTO DA CULTURA DO FEIJÃO COM DIFERENTES LÂMINAS DE IRRIGAÇÃO E DOSAGENS DE NITROGÊNIO POR PARÂMETROS ESPECTRAIS}

\section{RESUMO}

O objetivo deste trabalho foi analisar o impacto de diferentes doses de nitrogênio e lâminas de irrigação sobre os parâmetros biofísicos (Índice de Área Foliar - IAF) e espectrais obtidos com o método da remoção de feições espectrais contínuas (profundidade e área de banda) sobre a cultura do feijão e determinar o estádio de desenvolvimento da cultura que melhor se correlacionou com o IAF. A banda de absorção, na região do visível posicionada em $665 \mathrm{~nm}$, foi analisada em termos de profundidade e largura de banda. Medidas de reflectância foram adquiridas ao longo de seis estádios fenológicos da cultura em 48 parcelas, com quatro lâminas de irrigação $(179,5 ; 256,5 ; 357,5$ e 406,2 mm), três doses de $\mathrm{N}(0 ; 80$ e $160 \mathrm{~kg}$ ha-1) e quatro repetições. Os diferentes tratamentos mostraram que o aumento da concentração de nitrogênio não proporcionou o aumento da área da banda de absorção $\left(A_{B}\right)$, como também a profundidade 
da banda de absorção $\left(\mathrm{P}_{\mathrm{B}}\right)$. Por outro lado, as lâminas de irrigação afetaram tanto a $\mathrm{A}_{\mathrm{B}}$ quanto a $\mathrm{P}_{\mathrm{B}}$, para praticamente todos os estádios de desenvolvimento da cultura. As melhores correlações entre o IAF e os parâmetros da banda de absorção foram observadas no estádio R6.

Palavras-chave: Phaseolus vulgaris, sensoriamento remoto, espectroradiometria, hiperespectral, remoção do contínuo

\section{INTRODUCTION}

Bean plant is highly dependent on nutrient, mainly because of its short-depth root system and short life cycle (90-110 days) (DOURADO NETO \& FANCELLI, 2007). So, nitrogen fertilization is an important management technique necessary to achieve high yield potential in irrigated agricultural systems (SANT'ANA et al., 2011).

Bean yield is also widely affected by water conditions of the soil. Deficiency or excess of water, in different stages of the crop's cycle causes productivity reduction in different proportions (SOUSA et al., 2009). Therefore, the knowledge of water consumption crop obtained by evapotranspiration is important information to adequate water management (PIVETTA, et al., 2010).

An increase in the $\mathrm{N}$ concentration and the water conditions of crops produces spectral reflectance changes that may be detected by remote sensing instruments, as demonstrated by several researchers (TILLING, et al., 2007; FENG et al., 2008).

Most of the studies to determine biophysical parameters of crops are based on vegetation indices (WU et al., 2008; GALVÃO et al., 2009), such as normalized difference vegetation index (NDVI). However, the major limitation of using NDVI is that it approaches a saturation level asymptotically for a certain range of biomass (THENKABAIL et al., 2000).

Therefore, methods that consider continuum and individual profile of reflectance spectra have been developed (MEER, 2000). Absorption bands associated with specific parameter like chlorophyll (665 $\mathrm{nm}$ ) can be extracted from spectra using the continuum removal method (CLARK \& ROUSH, 1984), which allow the determination of their depth $\left(\mathrm{P}_{\mathrm{B}}\right)$ and area $\left(A_{B}\right)$. This methodology can be applied by laboratory, field, airborne or orbital spectrometers. Only a few studies have addressed spectral feature analysis for determine biophysical parameter (ADAMI et al., 2010).

The objectives of this field experiment were to evaluate the impact of different water levels and $\mathrm{N}$ rates on biophysical (LAI) and spectral parameters obtained by continuum removal technique (depth and area of the absorption band) of bean and to determine the growth stage at those spectral parameters best correlated with LAI.

\section{MATERIAL AND METHODS}

This experiment was conducted at the research farm located in the Piracicaba municipally, São Paulo State, Brazil (22 42' $30^{\prime \prime} \mathrm{S}$ and $\left.47^{\circ} 38^{\prime} 39^{\prime \prime} \mathrm{W}\right)$. Bean canopies (Phaseolus vulgaris L., "Pérola" cultivar, variety LR 720982 CPL 53) were grown from September to December of 2007. According to the Koppen classification, the climate of this region is Cwa (humid subtropical with rain summer and dry winter).

During the growing season, the mean temperatures were 22.7, 24.0, 22.2 and $23.9^{\circ} \mathrm{C}$ in September, October, November and December, respectively. The precipitation amounts during the experimental months were $168.3 \mathrm{~mm}$. The 
average water demand for bean was approximately $3.5 \mathrm{~mm} \mathrm{day}^{-1}$, so water was complemented or supplemented with irrigation. The experimental site had been under fallow for two years and then cropped under the conventional tillage system.

The soil of the experimental site was an Oxisol. Chemical properties of soil of the 0-0.2 m-layer (RAIJ et al., 1997) are the following: $\mathrm{pH} 5.3$ (in $\mathrm{CaCl} 2$ ), $\mathrm{K} 4.5$ mmolc $\mathrm{dm}^{-3}, \mathrm{Ca} 42$ mmolc $\mathrm{dm}^{-3}, \mathrm{Mg} 9$ mmolc $\mathrm{dm}^{-3}$, $\mathrm{H}+\mathrm{Al} 34 \mathrm{mmolc} \mathrm{dm}^{-3}$, P 16 mmolc $\mathrm{dm}^{-3}$, organic matter $21 \mathrm{~g} \mathrm{dm}^{-3}$ and base saturation $62 \%$. The granulometric analysis indicated $360 \mathrm{~g} \mathrm{~kg}^{-1}$ clay, $37 \mathrm{~g} \mathrm{~kg}^{-1}$ silt, and $27 \mathrm{~g} \mathrm{~kg}^{-1}$ sand, respectively. Soil bulk density was $1.49 \mathrm{~kg} \mathrm{dm}^{-3}$.

The treatment composition was by water and $\mathrm{N}$ factorial, and experimental design was in randomized blocks with plots subdivided (split-plot design); plots included all four water levels $(179.5 ; 256.5 ; 357.5$ and $406.2 \mathrm{~mm}$ of water, according to GOMES et al., 2000; DOURADO NETO \& FANCELLI, 2007), denoted as W1, W2, W3 and W4, and subplots included three nitrogen rates at 0,80 and $160 \mathrm{~kg} \mathrm{ha}^{-1}$ (BARBOSA FILHO et al., 2005), denoted as $\mathrm{N} 0, \mathrm{~N} 1$ and $\mathrm{N} 2$, respectively, totalizing 12 treatments. Treatments were arranged in four blocks (replications), totalizing 48 experimental plots. Bean was sown on September 4th, 2007 with approximately 14 viable seeds per linear meter of row and seedlings emerged on September 10th, 2007. Planting rows were oriented north-south and spaced $0.5 \mathrm{~m}$ with seven rows per plot. Plots were $3.2 \mathrm{~m}$ long and $2.2 \mathrm{~m}$ wide.

Irrigation was applied using line source sprinkler system, according to Hans et al. (1976). An estimate of crop evapotranspiration was carried out by Penman-Monteith method (ALLEN et al., 1998) to determine crop water consumption and to compare it with the total amount applied during experimental period, in each water level. The amount of water applied in the initial crop stage was the same for all treatments $(38.3 \mathrm{~mm})$. Fifty days after sowing, there was a period of approximately 25 days in which there were considerable effective precipitations and therefore there was no need for irrigation.

Nitrogen fertilizer was ammonium sulfate, applied manually according to the fertilizer recommendations. One third of the total $\mathrm{N}$ dosage was applied in the seeding furrow, and the remaining was top-dressed at two equal rates on September 17th and October 06th, 2007, respectively, as sidedressing in a shallow furrow at $0.20 \mathrm{~m}$ from the planting row. Basic fertilization, potassium $(\mathrm{K})$ and phosphorus $(\mathrm{P})$, was done manually on the seeding furrow using $\mathrm{KCl}$ (90 Kg ha ${ }^{-1} \mathrm{~K} 2 \mathrm{O}$ ) and single superphosphate (100 Kg ha ${ }^{-1} \mathrm{P} 2 \mathrm{O5}$ ).

\section{Reflectance factor and leaf area index}

Remote sensing data consisted of conical-directional reflectance factor spectra collected using SPECTRON SE-590 portable field spectroradiometer, which operates from 350 to $1100 \mathrm{~nm}$ wavelengths of the electromagnetic spectrum. A $15^{\circ}$ IFOV (Instantaneous Field of View) lens was used, positioned at nadir $3 \mathrm{~m}$ above the canopy, maintained at a constant height irrespective of the plant growth stage, defining an area of approximately $0.48 \mathrm{~m}^{2}$ above the canopy.

Original reflectance data were resampled with a band interval of about 2.7 $\mathrm{nm}$, resulting in 252 bands. Radiometric measurements were carried when weather conditions were favorable (Table 1), that is, cloud-free days using the spectron SE-590.

Therefore, measurements were conducted between $11 \mathrm{~h} 00$ and $13 \mathrm{~h} 00$ (local time), the period in which the soil was almost totally illuminated (JACKSON et al., 1979), within approximately 2 hours off solar noon, attempting to standardize light conditions. 
Table 1. Radiometric measurements dates, corresponding days after sowing (DAS) and corresponding bean growth stages during experimental period.

\begin{tabular}{lclc}
\hline $\begin{array}{c}\text { Date of } \\
\text { Measurements }\end{array}$ & DAS & Growth Stage * & Short Name \\
\hline Sep $18^{\text {th }}, 2007$ & 14 & Plants recent emerged with one leaf & V2 \\
\hline Sep $29^{\text {th }}, 2007$ & 25 & The first trifoliolate leaf unfolded & V3 \\
\hline Oct $10^{\text {th }}, 2007$ & 36 & The third trifoliolate leaf unfolded & V4 \\
\hline Oct $29^{\text {th }}, 2007$ & 55 & First flowers developed & R6 \\
\hline Nov $18^{\text {th }}, 2007$ & 75 & Pods with fully developed seeds & R8 \\
\hline Nov $23^{\text {rd }}, 2007$ & 80 & $50 \%$ of pods changed colors (physiological maturity) & R9a \\
\hline Nov $30^{\text {th }}, 2007$ & 87 & $\begin{array}{l}80 \% \text { of pods changed colors and the leaves fall } \\
\text { (harvest maturity) }\end{array}$ & R9b \\
\hline
\end{tabular}

* The description of all phenological stages is from characteristics observed in $50 \%$ of plants, according to the growth stage description for bean given by Fancelli (2009).

Radiometric measurements were taken using the following protocol: (i) For each plot, two pairs of spectrums (sample and reference) were collected, that is, four radiance measurements, two of the canopy and two of the reference plate (Barium sulfate), obtaining a reflectance factor in each plot at the end of each reading; (ii) The reflectance factor was obtained by the ratio between the spectral radiance of the canopy and the spectral radiance of the reference plate, maintained under the same conditions of illumination and target geometry (MILTON, 1987).

Non-destructive LAI measurements were performed early in the morning, when there was more diffuse and less direct solar radiation, with a LAI-2000 Plant Canopy Analyzer. LAI measurements were made on six dates: 1) October 01, 2007 (V3); 2) October 10, 2007 (V4); 3) November 1, 2007 (R6); 4) November 19, 2007 (R8); 5) November 24, 2007 (R9 - physiological maturity) and 6) December 1, 2007 when (R9 - harvest maturity), according to the growth stage description for bean given by Fancelli (2009).

\section{Continuum removal}

Continuum removal technique is used to evaluate hyperspectral reflectance spectra. This technique consists on removing continuum profiles of spectrum, where the continuum is a linear function used to isolate specific absorption bands of reflectance spectrum, improving the spectral analyses (CLARK \& ROUSH, 1984) (Figure 1). This technique highlights the absorption features, minimizing the influence of external factors.

For this study, the absorption band was set between 550 and $800 \mathrm{~nm}$ and the central $\lambda$ chosen as reference was positioned at $665 \mathrm{~nm}$ (Figure 1B), according to Gao (1996), Curran et al. (2001) and Galvão et al. (2005). The selected region is mainly influenced by chlorophyll absorption (JACQUEMOUD et al., 1996). Due to the characteristics of SPECTRON SE-590 can only consider this absorption band. Other absorption bands, e.g. leaf water content (950 to $1015 \mathrm{~nm}$ ) are positioned in a spectral region where the measurements have noise or not performed by this unit.

After continuum removal, two spectral parameters (band depth $\mathrm{P}_{\mathrm{B}}$ and band area $A_{B}$ ) can be obtained. Absorption band depth $\left(\mathrm{P}_{\mathrm{B}}\right)$ is related to the quantity of energy demanded by the element that caused absorption. 
(A)

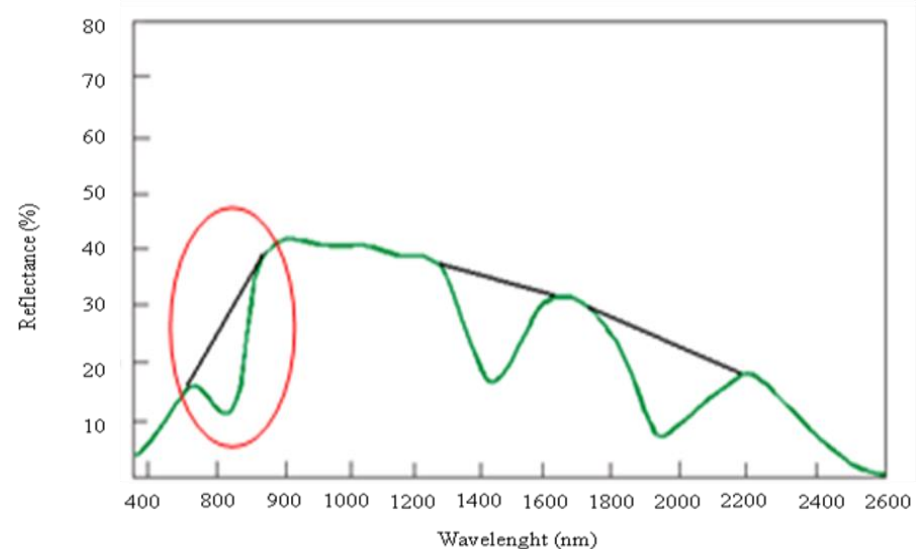

(B)

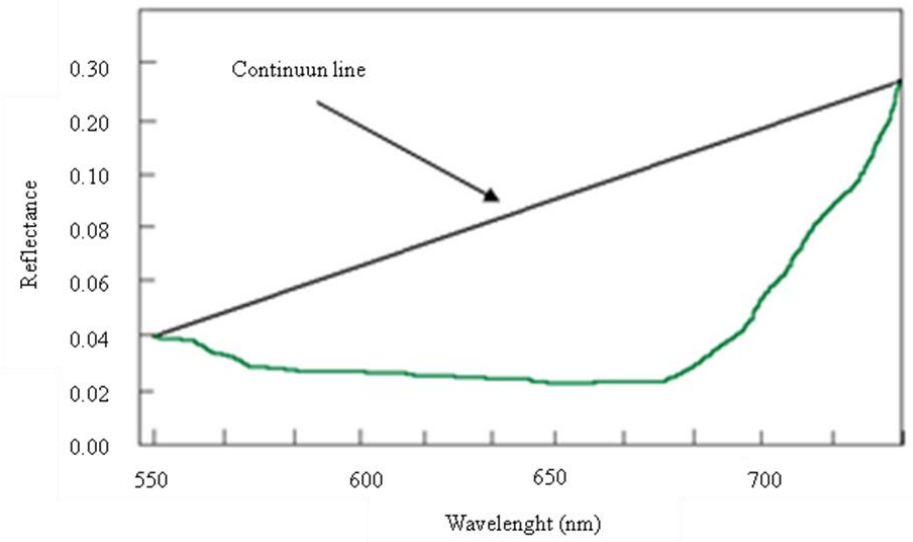

(C)

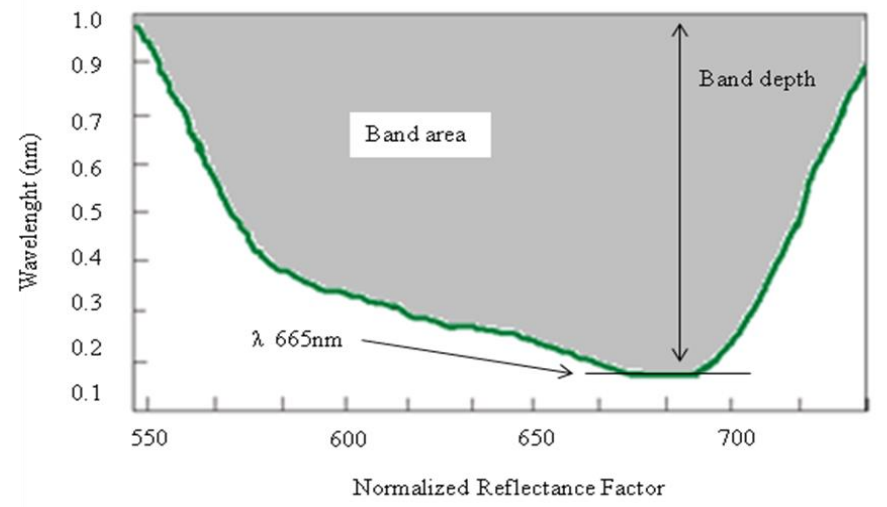

Figure 1. Schematic representation of continuum removal. Reflectance spectrum of green vegetation (A); Continuum lines delimiting the edge of the studied absorption band (chlorophyll at $665 \mathrm{~nm}$ ) (B); Normalized reflectance spectrum after continuum removal to isolate the absorption band and to allow the calculation of their depth and area (C). Adapted from Pu et al. (2003). 
The absorption band was positioned at $\lambda 665 \mathrm{~nm}$, based on former studies Gao (1996) and Curran et al. (2001). Eq. 1 (KOKALY \& CLARK, 1999; ADAMI et al., 2010) is used for the calculus of $\mathrm{P}_{\mathrm{B}}$.

$$
\mathrm{P}_{\mathrm{B}}=\left(1-\rho_{\mathrm{CR} \lambda}\right)
$$

where:

the $\rho_{\mathrm{CR} \lambda}$ is the reflectance factor with the spectral continuum features removed.

Absorption band area $\left(\mathrm{A}_{\mathrm{B}}\right)$ was calculated by numerical proximity given by Eq. 2, which considers the area of the trapezoid in each interval of $\lambda$ measured by the sensor between the limits $\mathrm{m}(550 \mathrm{~nm})$ and $\mathrm{M}(800 \mathrm{~nm})$.

Absorption band width is given by determining previous and posterior positions with $\lambda$ of higher depth referring to half of the maximum (PU et al., 2003; ADAMI et al., 2010).

$$
A_{\text {B }}=\sum_{\mathrm{i}=\mathrm{m}}^{\mathrm{M}} \frac{\left(\rho_{\mathrm{i}}+\rho_{\mathrm{i}-1}\right)}{2} \cdot\left(\lambda_{\mathrm{i}}-\lambda_{\mathrm{i}-1}\right)
$$

where:

$A_{B}$ is the absorption band area, $i$ represents the $\lambda$ interval measured by the sensor along the spectrum between the absorption band limits $\mathrm{m}$ and $\mathrm{M}(550$ and $800 \mathrm{~nm}$, respectively).

The $\rho$ is the normalized conical-directional reflectance factor and the $\lambda$ interval is defined by spectral resolution of the sensor

To evaluate the impact of the water levels and $\mathrm{N}$ rates on the biophysical (LAI) and spectral parameters $\left(\mathrm{A}_{\mathrm{B}}\right.$ and $\left.\mathrm{P}_{\mathrm{B}}\right)$, the following statistical procedures were used: (i) ANOVA to determine whether treatment means differed from each other, and (ii) $\mathrm{F}$ test $(\mathrm{p} \leq 0.05$ and $\mathrm{p} \leq 0.01)$. The SAS statistical software was used.

\section{RESULTS AND DISCUSSION}

\section{Effects of treatments on biophysical parameter}

The ANOVA of the LAI values showed that only the water factor affected the mean values (Table 2). Therefore the relatively large variations observed in the LAI are mainly attributed to different irrigation treatments. Water affected LAI in every bean growth stages, except on V2 stage. $\mathrm{N}$ did not affect LAI during all analyzed growth stages, whereas Adami et al. (2010) found that $\mathrm{N}$ affected the LAI values in comparison with treatments without $\mathrm{N}$ input.

This behavior was probably due to the fact that the experimental area has gone through a under fallow period by two years and other experiments with legume crops were conducted at this experimental area, so the soil could have a reasonable amount of $\mathrm{N}$ when the bean crop was sown. The low response is expected to nitrogen applied in fallow soil for two or more years or in soil with a previous legume crop, according to Raij et al. (1997). The interaction between N and $\mathrm{W}$ had not affected the LAI in any bean growth stages.

Leaf area index (LAI) ranged from $1.39 \mathrm{~m}^{2} \mathrm{~m}^{-2}$ to $8.30 \mathrm{~m}^{2} \mathrm{~m}^{-2}$, on R6 stage (58 DAS) which is a greater vegetative growing stage. These results are similar to those found by Gomes et al. (2000) in which the maximum IAF value was $8.6 \mathrm{~m}^{2} \mathrm{~m}^{-2}$ and by Urchei et al. (2000) that the highest values of LAI were at 58 DAS.

\section{Effects of treatments on spectral parameters $\left(A_{B}\right.$ and $\left.P_{B}\right)$}

The analysis of variance also revealed that absorption band area $\left(A_{B}\right)$ and the absorption band depth $\left(\mathrm{P}_{\mathrm{B}}\right)$ were influenced just by water factor. 
Tables 3 and 4 show results from the analysis of variance applied to $A_{B}$ and to $P_{B}$ of the absorption band centered at $665 \mathrm{~nm}$ (chlorophyll), for the growth stages of V2 (September 18, 2007), V3 (September 29, 2007), V4 (October 10, 2007), R6 (October 29, 2007), R8 (November 18, 2007), R9a (November 23, 2007) and R9b (November 30, 2007).

The $\mathrm{N}$ had no significant effect on $A_{B}$ and $P_{B}$. These results are different than expected that present a widening and deepening of the absorption feature with an increase in nitrogen supply. According to Adami et al., (2010), during initial development, plant growth is positively affected by increased $\mathrm{N}$ availability, producing more green biomass and LAI. A possible explanation to this behavior is that the soil already had a sufficient supply of $\mathrm{N}$ to the crop due to the under fallow period and by legume crop residues previously sown. These crop residues have high levels of $\mathrm{N}$ and consequently low $\mathrm{C} / \mathrm{N}$ ratio causing a relatively fast decomposition, with significant availability of nitrogen to subsequent crops (AITA et al., 2004).

On the other hand, water levels showed significant effects on these spectral parameters in all seven growth stages analyzed, except on V2 stage for $A_{B}$ (Table 3 ) and $R 8$ stage for $P_{B}$ (Table 4). The interaction between nitrogen $(\mathrm{N})$ and water (W) had effect on $A_{B}$ for V4 and R6 stages and had effect on $\mathrm{P}_{\mathrm{B}}$ for V4 stage. The unfolding of the $\mathrm{N}$ source of variation in each water level show that $\mathrm{N}$ influenced $\mathrm{A}_{\mathrm{B}_{-}} \mathrm{V} 4$ at all water levels, $\mathrm{A}_{\mathrm{B}_{-}} \mathrm{R} 6$ at $\mathrm{W}_{1}=$ $180 \mathrm{~mm}$ and $\mathrm{W}_{4}=406 \mathrm{~mm}$ and $\mathrm{P}_{\mathrm{B}_{-}} \mathrm{V} 4$ at $\mathrm{W}_{3}$ $=358 \mathrm{~mm}$. Water treatments influenced $\mathrm{A}_{\mathrm{B}_{-}} \mathrm{V} 4, \mathrm{~A}_{\mathrm{B}_{-}} \mathrm{R} 6$ and $\mathrm{P}_{\mathrm{B}_{-}} \mathrm{V} 4$ in all $\mathrm{N}$ treatments. These results agree with results early reports in other crops (MUTANGA et al., 2004; ADAMI et al., 2010).

Values of $A_{B}$ and $P_{B}$ were smaller during the initial stages (V2 and V3), in which bean was in initial stage and $\mathrm{R} 9$ stages (R9a and R9b), in which bean onset in senescence (ADAMI et al., 2010; MONTEIRO et al., 2012). The behavior for the chlorophyll absorption band $(665 \mathrm{~nm})$ presented slightly larger $P_{B}$ and $A_{B}$ values in R6 stage than in the V4 stage. This fact might be attributed to the adequate water content for the plant that promoted the photosynthetic activity and a LAI increase. During the R9a and R9b stages, the spectral reflectance of bean canopy tends to increase in the red band due to reduce photosynthetic activity of the leaves and decrease in the near infrared range to reduce multiple scattering (ADAMI et al., 2010), which reduced the $A_{B}$ and $P_{B}$ values.

Results for the association of LAI with $A_{B}$ and $P_{B}$ values showed that the $P_{B}$ is related to the energy absorbed in a specific wavelength, whereas $A_{B}$ comprise all the energy absorbed by crops in a broad spectral interval around the feature (CLARK \& ROUSH, 1984; KOKALY \& CLARK, 1999) .

Table 2. Analysis of variance of leaf area index (LAI) under irrigation levels and $\mathrm{N}$ doses.

\begin{tabular}{|c|c|c|c|c|c|c|c|}
\hline \multirow{3}{*}{ Factors } & \multicolumn{7}{|c|}{ Days after sowing } \\
\hline & $21(\mathrm{~V} 3)$ & $28(\mathrm{~V} 3)$ & 37 (V4) & 59 (R6) & $77(\mathrm{R} 8)$ & 82 (R9a) & 89 (R9b) \\
\hline & \multicolumn{7}{|c|}{ Mean } \\
\hline Irrigation (a) & $1.53^{\mathrm{ns}}$ & $9.00 * *$ & $88.95 * *$ & $147.27 * *$ & $48.74 * *$ & $74.62 * *$ & $24.59 * *$ \\
\hline Nitrogen (b) & $0.65^{\mathrm{ns}}$ & $0.16^{\mathrm{ns}}$ & $1.47^{\mathrm{ns}}$ & $3.32^{\mathrm{ns}}$ & $1.15^{\mathrm{ns}}$ & $1.89^{\mathrm{ns}}$ & $2.94 * *$ \\
\hline $\begin{array}{l}\text { Interaction } \\
(\mathrm{a} * \mathrm{~b})\end{array}$ & $0.78^{\mathrm{ns}}$ & $0.56^{\mathrm{ns}}$ & $1.84^{\mathrm{ns}}$ & $5.51 * *$ & $1.36^{\mathrm{ns}}$ & $0.75^{\mathrm{ns}}$ & $5.30 * *$ \\
\hline
\end{tabular}


Table 3. Analysis of variance for area $\left(A_{B}\right)$ values of the absoption band centered at $665 \mathrm{~nm}$.

\begin{tabular}{lccccccc}
\hline \multirow{2}{*}{ Factors } & \multicolumn{7}{c}{ Days after sowing } \\
\cline { 2 - 7 } & $14(\mathrm{~V} 2)$ & $25(\mathrm{~V} 3)$ & $36(\mathrm{~V} 4)$ & $55(\mathrm{R} 6)$ & $75(\mathrm{R} 8)$ & $80(\mathrm{R} 9 \mathrm{a})$ & $87(\mathrm{R} 9 \mathrm{~b})$ \\
\hline & \multicolumn{7}{c}{ Mean } \\
\hline Irrigation & $1.60^{*}$ & $4.10^{* *}$ & $2408.97^{* *}$ & $1068.80^{* *}$ & $4.38^{*}$ & $15.88^{* *}$ & $87.51^{* *}$ \\
\hline Nitrogen & $1.16^{\mathrm{ns}}$ & $2.98^{\mathrm{ns}}$ & $0.48^{\mathrm{ns}}$ & $0.43^{\mathrm{ns}}$ & $3.12^{\mathrm{ns}}$ & $1.17^{\mathrm{ns}}$ & $0.32^{\mathrm{ns}}$ \\
\hline Interaction & $2.76^{\mathrm{ns}}$ & $2.18^{\mathrm{ns}}$ & $13.28^{* *}$ & $5.45^{* *}$ & $0.57^{\mathrm{ns}}$ & $0.48^{\mathrm{ns}}$ & $0.42^{\mathrm{ns}}$ \\
\hline
\end{tabular}

** Significant at the $5 \%$ and $1 \%$ levels, respectively; ns - not significant

Table 4. Analysis of variance for deph $\left(\mathrm{P}_{\mathrm{B}}\right)$ values of the absoption band centered at $665 \mathrm{~nm}$.

\begin{tabular}{llllllll}
\hline \multirow{2}{*}{ Factors } & \multicolumn{7}{c}{ Days after sowing } \\
\cline { 2 - 7 } & $14(\mathrm{~V} 2)$ & $25(\mathrm{~V} 3)$ & $36(\mathrm{~V} 4)$ & $55(\mathrm{R} 6)$ & $75(\mathrm{R} 8)$ & $80(\mathrm{R} 9 \mathrm{a})$ & $87(\mathrm{R} 9 \mathrm{~b})$ \\
\cline { 2 - 7 } & & \multicolumn{7}{c}{ Mean } \\
\hline Irrigation & $3.51^{\mathrm{ns}}$ & $3.87^{*}$ & $103.31^{* *}$ & $1076.06^{* *}$ & $3.41^{\mathrm{ns}}$ & $9.87^{* *}$ & $91.58^{* *}$ \\
\hline Nitrogen & $1.59^{\mathrm{ns}}$ & $2.97^{\mathrm{ns}}$ & $1.16^{\mathrm{ns}}$ & $0.39^{\mathrm{ns}}$ & $1.35^{\mathrm{ns}}$ & $0.93^{\mathrm{ns}}$ & $0.05^{\mathrm{ns}}$ \\
\hline Interaction & $2.05^{\mathrm{ns}}$ & $2.18^{\mathrm{ns}}$ & $4.35^{* *}$ & $2.14^{\mathrm{ns}}$ & $0.52^{\mathrm{ns}}$ & $0.44^{\mathrm{ns}}$ & $0.36^{\mathrm{ns}}$ \\
\hline$* *$ Significant at the $5 \%$ and $1 \%$ levels, respectively; ns - not significant
\end{tabular}

According to previous studies (MUTANGA et al., 2004; ADAMI et al., 2010; MONTEIRO et al., 2012), best correlations were observed at later reproductive stages (V4 to $\mathrm{R} 6$ ) than at earlier stages of bean development (V2 to V3). In the present study, this behavior was observed showing increase values from V4 to R6 stage and decrease from $\mathrm{R} 8$ to $\mathrm{R} 9$ stages. Correlations of LAI with $\mathrm{P}_{B}$ and $\mathrm{A}_{B}$ were better in the R6 stage (average of 0.87 and 0.89 , respectively) than in the V4 stage (average of 0.86 and 0.88 , respectively). In the R6 stage, the range of correlation coefficients was less variable than in the other stages. So, in agreement with previous results, higher values of average correlation coefficients were observed in the R6 stage for the relationships of LAI with spectral parameters $\left(A_{B}\right.$ and $\left.P_{B}\right)$. Figure 2 shows the continuum removal in the spectral interval between 550 and $800 \mathrm{~nm}$, changing greatly with different growth stages and between treatments. Vegetation presents a smaller amount of green biomass at initial, V2 to V3 stages, and higher amount of green biomass at later stages, V4 to R9a. Therefore, Figure 2 shows the stages with higher amount of green biomass (V4, R6, R8, R9a and R9b) presenting a better differentiation among treatments. The width of this absorption band is directly associated with the quantity of energy absorbed to make photosynthesis and with the chlorophyll content (JACQUEMOUD et al., 1996).

At fourteen days after sowing (DAS), vegetation was in its initial stage (V2) of development and had a smaller amount of green biomass, resulting in reflectance with a lot of influence from the soil and, therefore, the values of reflectance in this absorption stage were greater than in other dates. Twenty-five DAS, V3 stage, the differentiation in the level of water applied occurred. The absorption band starts to show a greater depth with the increasing irrigation level. The greater band depth means the higher electromagnetic radiation absorption because of the increase in plant foliar area and its concentration of chlorophyll. Such an increase resulted in larger values of band depth and band width and in better-defined chlorophyll absorption bands because these features are also sensitive to LAI (GAO, 1996). Therefore, treatments receiving a larger amount of water presented a greater depth and area of the absorption band (Figures 2A and 2B). 

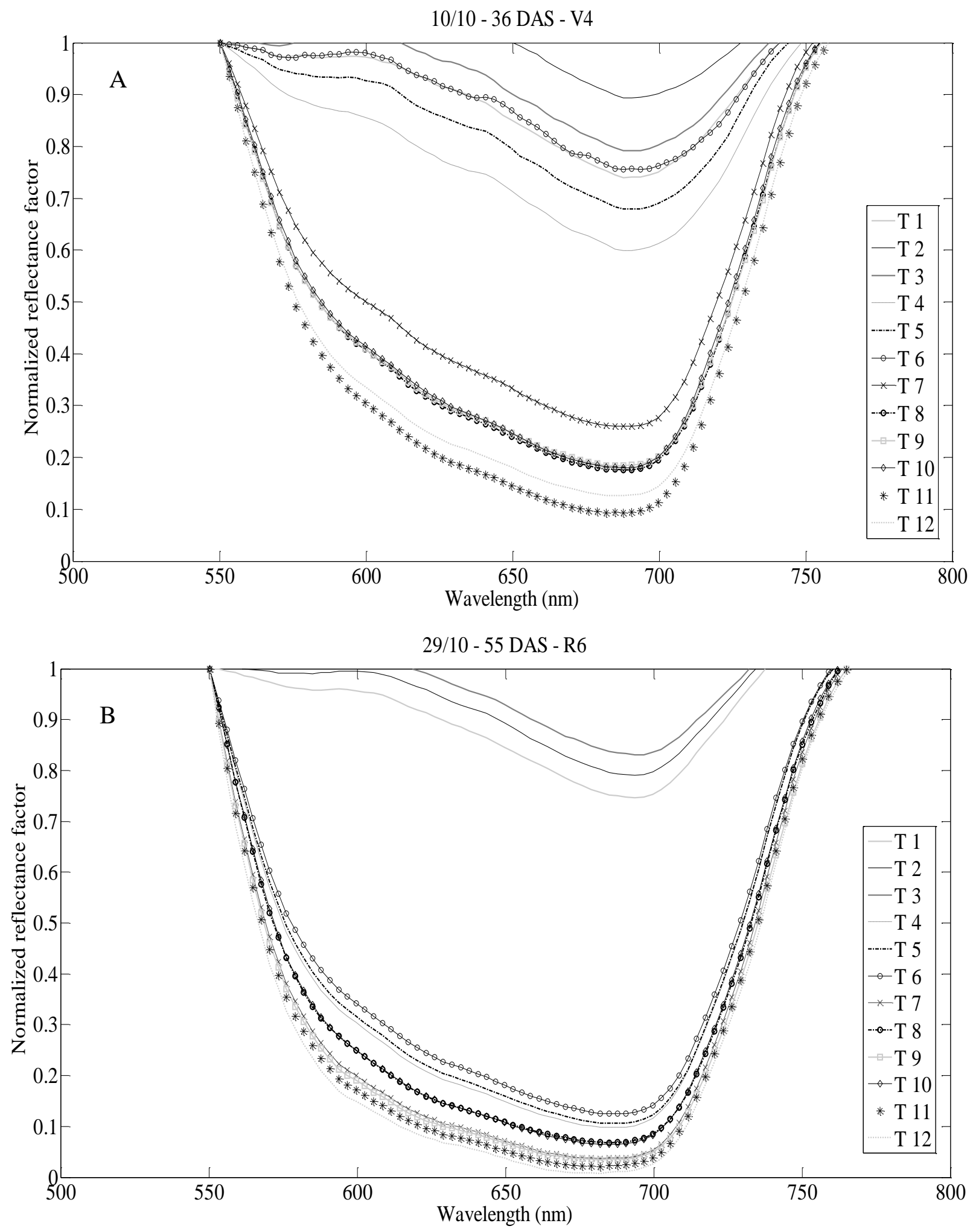

Continue... 

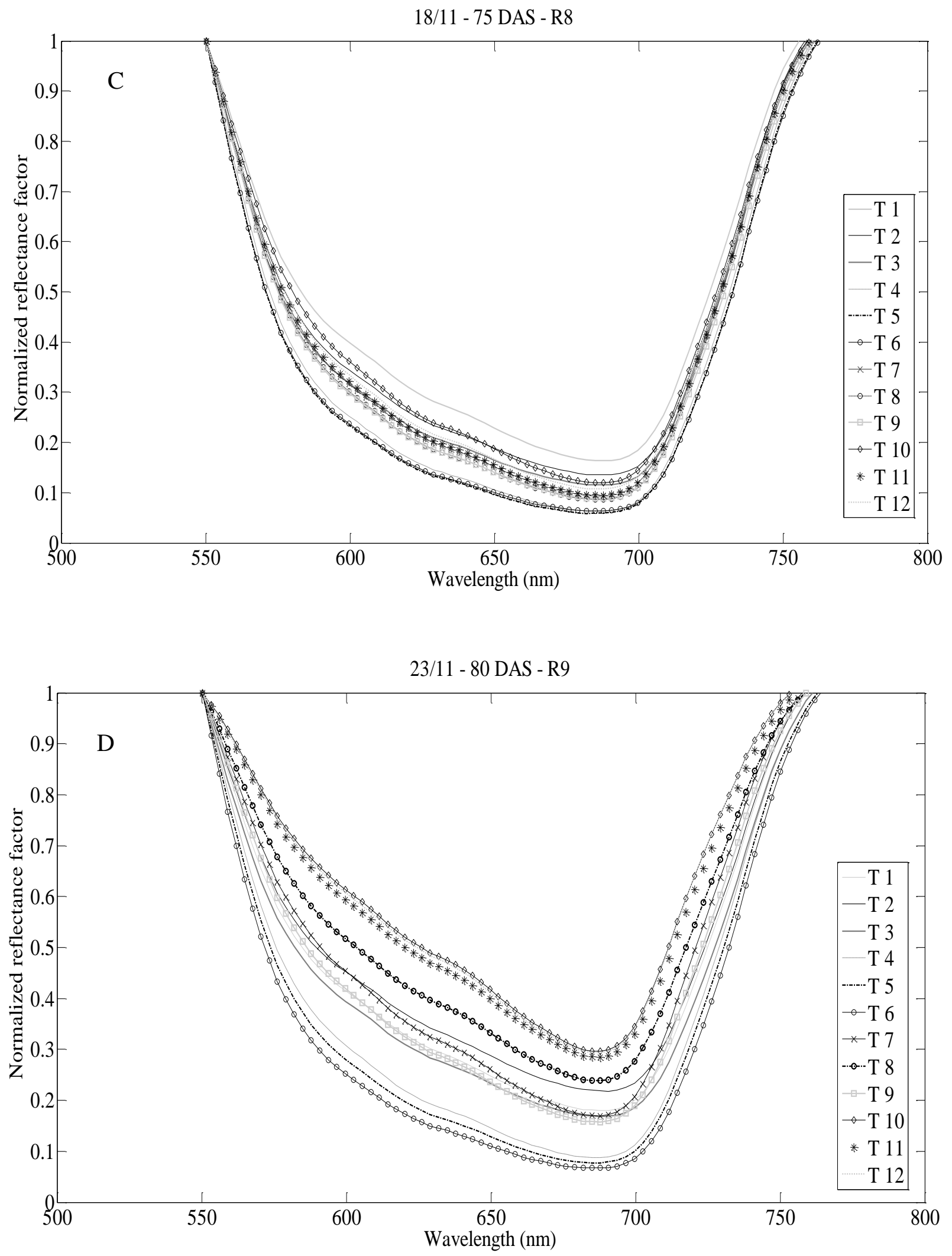

Continue... 


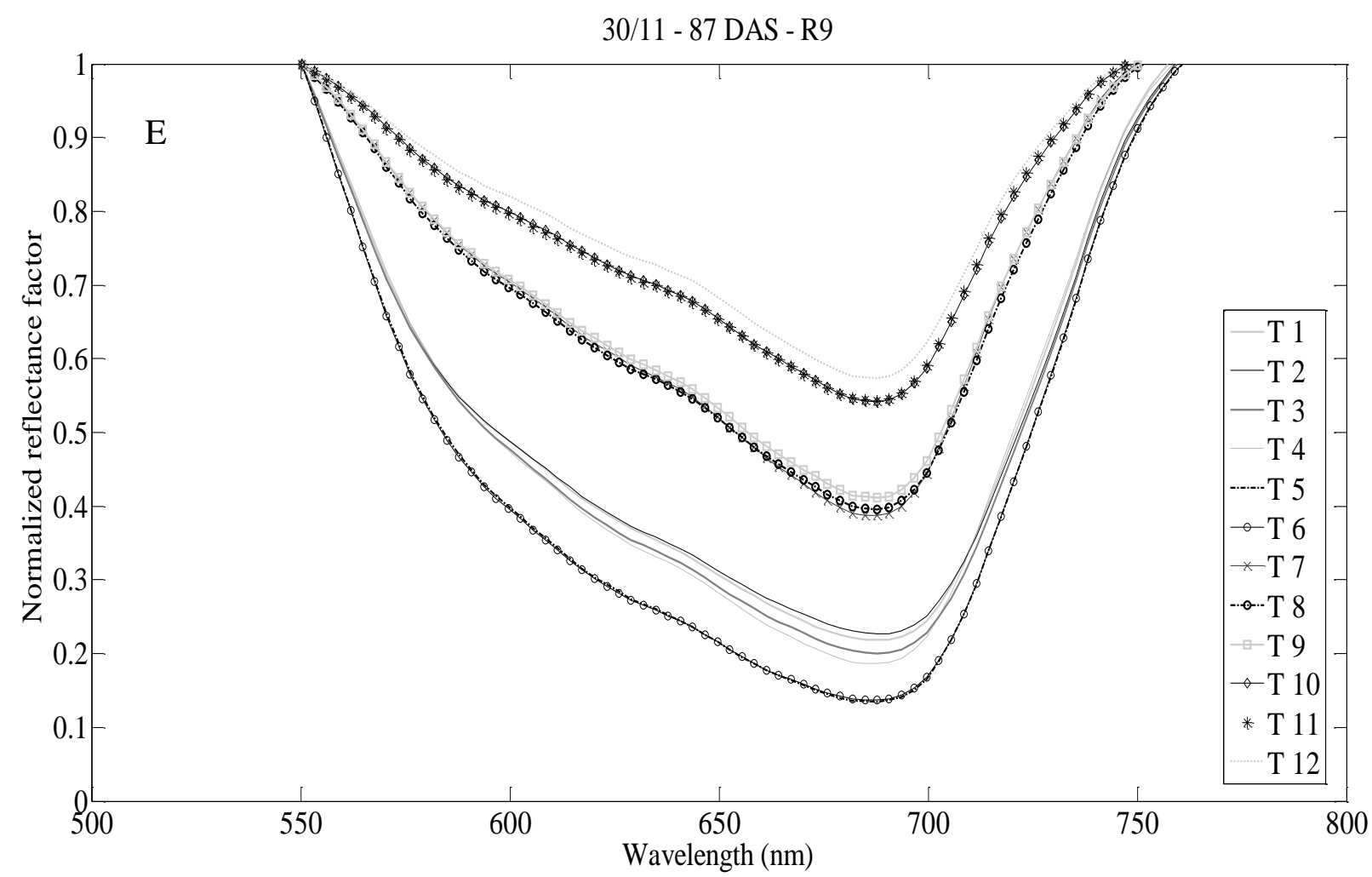

Figure 2. Continuum removal applied between 550 and $800 \mathrm{~nm}$ in different growth stages of bean crop for 12 treatments: T1 (W1=180 $\mathrm{mm}$ and no $\mathrm{N})$; T2 $(\mathrm{W} 1=180 \mathrm{~mm}$ and $\left.\mathrm{N} 1=80 \mathrm{~kg} \mathrm{ha}^{-1}\right)$; T3 (W1=180 $\mathrm{mm}$ and N2=160 kg ha $\left.{ }^{-1}\right)$; 4 (W2=257 $\mathrm{mm}$ and no $\mathrm{N})$; T5 (W2=257 mm and N1=80 kg ha $\left.{ }^{-1}\right)$; T6 (W2=257 mm and N2=160 kg ha $\left.{ }^{-1}\right)$; T7 (W3=358 mm and no N); T8 (W3=358 $\mathrm{mm}$ and $\left.\mathrm{N} 1=80 \mathrm{~kg} \mathrm{ha}^{-1}\right)$; T9 (W3=358 $\mathrm{mm}$ and $\left.\mathrm{N} 2=160 \mathrm{~kg} \mathrm{ha}^{-1}\right)$; T10 (W4=406 $\mathrm{mm}$ and no $\left.\mathrm{N}\right)$; T11 (W4=406 mm and $\left.\mathrm{N} 1=80 \mathrm{~kg} \mathrm{ha}^{-1}\right)$; T12 (W4=406 mm and N2=160 kg ha-1).

On the contrary, treatments receiving less water, independent of the $\mathrm{N}$ rate showed a lower absorption (Figure 2A and 2B) explained by a lower development of plant biomass and chlorophyll content and consequently a higher percentage of exposed soil which influence canopy spectral properties, confirming previous literature (ADAMI et al., 2010; MONTEIRO et al., 2012).

After 50 DAS all treatments received the same amount of water, so treatments receiving lower quantities of water showed good recovery (Figure 2D). All treatments presented increased electromagnetic radiation absorption (Figure 2D) when compared to the previous date (Figure 2C).
Even with a period of effective precipitation there was a delay in the bean cycle for treatments that received lower amounts of water. These plants had a longer cycle, resulting in a late harvest of the plots. These treatments ( $\mathrm{T} 1$ to $\mathrm{T} 6$ ) continued the process of photosynthesis while the others already were in senescence (Figure 2E).

\section{CONCLUSIONS}

The evaluation of the impact of different water levels and $\mathrm{N}$ treatments on spectral parameters $\left(A_{B}\right.$ and $\left.P_{B}\right)$ of bean canopy showed that water levels were the limiting factor. Spectral parameters 
presented increased values from V4 to $\mathrm{R} 8$ stages in response to water levels.

The performance of absorption band parameters is considered good to estimate biophysical parameters at $665 \mathrm{~nm}$.

The best correlations between LAI and absorption band parameters were observed at R6 stage, indicating that it is the best time to acquire remote sensing data to estimate grain yield.

Overall, the successful use of absorption features for predicting biophysical variables at field level is an important step towards the remote sensing on the forecasting crop yield. These results have important implications for agriculture not only for crop yield but also for understanding the canopy biochemical concentration in growth stages of the crops.

\section{ACKNOWLEDGMENTS}

The authors thanks CAPES (Coordenação de Aperfeiçoamento de Pessoal de Nível Superior) for the doctoral scholarship and FEALQ (Fundação de Estudos Agrários Luiz de Queiroz) for financial support.

\section{REFERENCES}

ADAMI, M.; RUDORFF, B.F.T.; BREUNIG, F.M.; PONZONI, F.J.; GALVÃO, L.S.; MOREIRA, M.A.; FREITAS, J.G.; SALA, V.M.R. 2010. Effect of Nitrogen and Endophytic Bacteria on Biophysical and Spectral Parameters of Wheat Canopy. Agronomy Journal, v.102, p.544-552.

AITA, C.; GIACOMINI, S.J.; HUBNER, A.P.; CHIAPINOTTO, J.C.; FRIES, M.R. 2004. Cover crop mixtures preceding notill corn. I - Soil nitrogen dynamics. Revista Brasileira de Ciência do Solo, v.28, p.739-749.

ALLEN, R.G.; PEREIRA, L.S.; RAES, D.; SMITH, M. $\quad$ 1998. Crop evapotranspiration: guidelines for computing crop water requirements. Rome: FAO. 328p. FAO Irrigation and Drainage Paper, 56.

BARBOSA FILHO, M.P.; FAGERIA, N.K., SILVA, O.F. 2005. Sources, rates and fractional topdressing of nitrogen fertilizers for irrigated common bean. Ciência Agrotecnologia, v.29, p.69-76.

CLARK, R.N.; ROUSH, T.L. 1984. Reflectance spectroscopy: quantitative analysis techniques for remote sensing applications. Journal of Geophysical Research, v.89, p.6329-6340.

CURRAN, P.J., DUNGAN, J.L.; PETERSON, D.L. 2001. Estimating the foliar biochemical concentration of leaves with reflectance spectrometry: Testing the Kokaly and Clark methodologies. Remote Sensing of Environment, v.76, p.349-359.

DOURADO NETO, D.; FANCELLI, A.L. 2007. Bean production. Piracicaba: Livroceres. 386p.

FANCELLI, A.L. 2009. Bean: Special topics in management. Piracicaba: Livroceres. 372p.

FENG, W., YAO, X., ZHU, Y., TIAN, Y.C.; CAO, W. 2008. Monitoring leaf nitrogen status with hyperspectral reflectance in wheat. European Journal of Agronomy, v.28, p.394-404.

GAO, B. 1996. NDWI: A normalized difference water index for remote sensing of vegetation liquid water from space. Remote Sensing of Environment, v.58, p.257-266.

GALVÃO, L.S.; FORMAGGIO, A.R.; TISOT, D.A. 2005. Discrimination of sugarcane varieties in southeastern Brazil Hyperion data. Remote Sensing of Environment, v.94, p.523-534.

GALVÃO, L.S.; ROBERTS, D.A.; FORMAGGIO, A.R.; NUMATA, I.; BREUNIG. F.M. 2009. View angle effects on the discrimination of soybean varieties and on the relationships between 
vegetation indices and yield using offnadir Hyperion data. Remote Sensing of Environment, v.113, p.846-856.

GOMES, A.A., ARAÚJO, A.P., ROSSIELLO, R.O.P., PIMENTEL, C. 2000. Accumulation of biomass, physiological characteristics and grain yield of bean cultivars under irrigated and dry regimes. Pesquisa Agropecuária Brasileira, v.35, p.1927-1937.

HANS, R.J.; KELLER, J.; RASMUSSEN, V.P.; WILSON, G.D. 1976. Line source sprinkler for continuous variable irrigation crop production studies. Soil Science Society of America Journal, v.40, p.426-429.

JACKSON, R.D.; PINTER JR., P.J.; IDSO, S.B.; REGINATO, R.J. 1979. Wheat spectral reflectance: interactions between crop configuration, sun elevation, and azimuth angle. Applied Optics, v.18, p.3730-3732.

JACQUEMOUD, S.; USTIN, S.L.; VERDEBOUT, J.; SCHMUCH， G.; ANDREOLI, G.; HOSGOOD, B. 1996. Estimating leaf biochemistry using the prospect leaf optical properties model. Remote Sensing of Environment, v.56, p.194-202.

KOKALY, R.F.; CLARK, R.N. 1999. Spectrocopic determination of leaf biochemistry using band-depth analysis af absortion features and stepwise multiple linear regression. Remote Sensing of Environment, v.67, p.267-287.

MEER, F. VAN DER. 2000. Spectral curve shape matching with a continuum removal CCSM algorithm. International Journal of Remote Sensing, v.21, p.3179-3185.

MILTON, E.J. 1987. Principles of field spectroscopy. International Journal of Remote Sensing, v.8, p.1807-1827.

MONTEIRO, P.F.C.; ANGULO FILHO, R.; XAVIER, A.C.; MONTEIRO, R.O.C. 2012. Assessing biophysical variable parameters of bean crop with hyperspectral measurements. Scientia Agricola, v.69, n.2, p.87-94.

MUTANGA, O.; SKIDMORE, A.K.; PRINS, H.H.T. 2004. Predicting in situ pasture quality Kruger National Park, South Africa, using continuum-removed absorption features. Remote Sensing of Environment, v.89, p.393-408.

PIVETTA, C.R.; HELDWEIN, A.B.; MALDANER, I.C.; RADONS, S.R.; TAZZO, I.F.; LUCAS, D.D. 2010. Evapotranspiração máxima do pimentão cultivado em estufa plástica em função de variáveis fenométricas e meteorológicas. Revista Brasileira de Engenharia Agrícola e Ambiental, v.14, p.768-775.

PU, R.; GE, S.; KELLY, N.M.; GONG, P. 2003. Spectral absortion features as indicators of water status in coast live oak (Quercus agrifolia) leaves. International Journal of Remote Sensing, v.24, p.1799-1810.

RAIJ, B. VAN.; QUAGGIO, J.A.; CANTARELLA, H.; ABREU, C.A. 1997. Results interpretation of soil analysis. In: Raij, B. van.; Cantarella, H.; Quaggio, J.A.; Furlani, A.M.C. (ed.). Liming and fertilizer recommendations for São Paulo state. 2ed. Campinas: IAC. 279 p. Boletim técnico, 100.

SANT'ANA, E.V.P.; SANTOS, A.B.; SILVEIRA, P. M. 2011. The efficiency of use of nitrogen apllied in top dressing in irrigated bean. Revista Brasileira de Engenharia Agricola e Ambiental, v.15, p.458-462.

SOUSA, M.A.; LIMA, M.D.B.; SILVA, M.V.V.; ANDRADE, J.W.S. 2009. Estresse hídrico e profundidade de incorporação do adubo afetando os componentes de rendimento do feijoeiro. Pesquisa Agropecuária Tropical, v.39, p.175-182.

THENKABAIL，P.S.; SMITH， R.B.; DE PAUW, E. 2000. Hyperspectral vegetation indices and their relationships with agricultural crop characteristics. 
Remote Sensing Environment, v.71, p.158-182.

TILLING, A.K.; O'LEARY, G.J.; FERWERDA, J.G.; JONES, S.D.; FITZGERALD, G.J.; RODRIGUEZ, D. AND BELFORD, R. 2007. Remote sensing of nitrogen and water stress in wheat. Field Crops Research, v.104, p.77-85.

URCHEI, M.A., RODRIGUES, J.D., STONE, L.F. 2000. Growth analysis of two bean cultivars under irrigation in no tillage and the conventional tillage. Pesquisa Agropecuária Brasileira, v.35, p.497-506.

WU, C.Y.; NIU, Z.; TANG; Q. HUANG. W. J. 2008. Estimating chlorophyll content from hyperspectral vegetation indices: Modeling and validation. Agricultural and Forest Meteorology, v.148, p.12301241.

Recebido em: 20/03/2013

Aceito para publicação em: 18/08/2013 